\title{
Technical Efficiency of Mushroom Farmers in Swaziland
}

\author{
Nkosingiphile P. Dlamini \\ P.O.Box C577, Hub Manzini, Swaziland
}

Micah B. Masuku (Corresponding author)

Department of Agricultural Economics and Management

P.O. Luyengo, Luyengo. M205, University of Swaziland

Tel: 268-7602-6557 E-mail: mbmasuku@uniswa.sz

\author{
Jeremiah I. Rugambisa \\ Department of Agricultural Economics and Management \\ P.O. Luyengo, Luyengo. M205, University of Swaziland \\ Tel:268-7607-6095 E-mail: jrugambis@uniswa.sz
}

Received: July 8, 2017 Accepted: September 4, 2017 Published: September 6, 2017

Doi: 10.5296/jab.v6i1.11811 URL: http://doi.org/10.5296/jab.v6i1.11811

\begin{abstract}
Mushrooms have been cultivated in Swaziland since 2001 as part of a long-term programme which sought to improve rural livelihoods through commercial production of non-conventional high-value commodities. Despite the mushroom enterprise gaining popularity in a number of Sub-Saharan African (SSA) countries, where production is dominated by rural-based small-scale farmers, limited research has been done to study the technical efficiency of mushroom farmers in Swaziland.The primary objectives of this study were to determine the level of technical efficiency of mushroom farmers in Swaziland and identify factors which influence technical efficiency of mushroom farmers. Measures of technical efficiency were conducted with 62 farmers in the four Agro ecological zones of Swaziland. The list of current mushroom farmers was obtained from the Mushroom
\end{abstract}


Development Unit in Malkerns. The Stochastic frontier production function was used to compute the level of technical efficiency (TE). The results revealed that the mean technical efficiency was $95 \%$. The results suggest that substantial gains in output can be attained by improving present technical practices which includes the increase in the amount of substrate used. A two limit Tobit regression technique was used to examine the relationship between $\mathrm{TE}$ and various farm and farmer characteristics. The results showed that household size was significant at 5\% level, technical assistance was also significant at 5\% and access to credit was significant at $10 \%$ level. It was recommended that extension officers equip farmers on technologies that will help boost their efficiency level and policies that will make access to credit from government and NGO's for mushroom farmers to acquire resources.

Keywords: Mushroom farmers, Stochastic frontier production function, Technical efficiency

\section{Introduction}

Swaziland is faced with the challenge of prevailing dry weather conditions, which makes it difficult to grow field crops like maize (Oseni \& Masarirambi, 2011). Mushrooms are not dependent on weather conditions such as rainfall and can be grown all year round through environmental manipulation. Hunger and Malnutrition is a problem in developing third world countries. Mushrooms with their flavour, texture, nutritional value and high productivity per unit area have been identified as an excellent food source to alleviate malnutrition in developing countries as well as improve the economy of African countries (Eswaran \& Ramabadran, 2000).

Currently, high biofuel prices have caused an increase in food prices and food scarcity in many countries (World Bank, 2008). To alleviate hunger and malnutrition in a world of rising food prices, cultivation of mushrooms is a reliable and profitable option. Measurement of technical efficiency (TE) provides useful information on competitiveness of farms and potential to improve productivity, with the existing resources and level of technology (Abdulai \& Tietje, 2007). Moreover, investigating factors that influence TE offers important insights on key variables that might be worthy of consideration in policy-making, in order to ensure optimal resource utilisation.

The measurement of efficiency in agricultural production determines the efficiency level of households in their farming activities. Farmers in developing countries do not use all potential technological resources, thus making inefficient decisions in their agricultural activities. According to the government of Swaziland's report (2013), 63\% of Swazis live below the poverty line. This study therefore is aimed at assessing the technical efficiency of mushroom farmers in Swaziland in order to curb the hunger and malnutrition problem facing Swaziland. This was achieved through the following specific objectives:

1) To describe the socio-economic characteristics of mushroom farmers that influence technical efficiency in Swaziland.

2) To determine the technical efficiency of mushroom growers in Swaziland.

3) To identify the factors that influence technical efficiency of mushroom production.

\section{Theoretical Framework}

Efficiency is considered as one of the most important issues in agricultural production 
economics. It is measured by comparing the actually attained value of the objective function against what is attainable at the production frontier. Hassanpour (2012) stated that the analysis of technical and allocative efficiencies under the current technological change in agriculture helps policy makers to formulate adequate and appropriate, extension services, pricing, marketing, and credit, input distribution and land allocation policies.

\subsection{Technical Efficiency}

In economic theory, a production function is described in terms of maximum output that can be produced from a specified set of inputs, given the existing technology available to the farm (Battese and Coelli., 1995). When the farm produces at the optimal production frontier, it is considered efficient. Technical Efficiency (TE) is achieved when a high level of output is realized given a minimum level of inputs. It is therefore concerned with the efficiency of the input to output transformation. The reason for TE research is to understand factors that shift production function upwards on the production frontier (Battese \& Coelli, 1995).

\subsection{Parametric Methods for Measuring Technical Efficiency}

The term frontier involves the concept of maximality in which the function sets a limit to the range of possible observations (Adeleke et al., 2008). It is therefore, possible to observe the points below the production frontier for firms or farms producing below the maximum possible output, but there cannot be any point above the production frontier, given the available technology. Parametric frontier approaches impose a functional form on the production function and any deviations from the frontier are attributed to inefficiency (Chirwa, 2003).

The parametric approach is composed of the stochastic frontier approach (SFA), the thick frontier approach (TFA) and the distribution free approach (DFA) (Kibaara, 2005). On the other hand, Adeleke et al. (2008) grouped these methods into deterministic, programming and stochastic, depending on how the frontier is specified.

The stochastic frontiers method is used in this study. This choice is made on the basis of the variability of agricultural production, which is attributable to climatic hazards, plant pathology and insect pests, on the one hand, and, on the other hand, because information gathered on production is usually inaccurate since small farmers do not have updated data on their farm operations. In fact, the stochastic frontier method makes it possible to estimate a frontier function that simultaneously takes into account the random error and the inefficiency component specific to every plantation.

According to Ajewole and Folayan (2008), the stochastic frontier production function generally assumes the presence of technical inefficiency and may be expressed as:

$$
Y_{i}=f\left(X_{i} ; \beta\right) \exp \left(V_{i}-U_{i}\right) \quad i=1,2 \ldots . N
$$

Where, $Y_{i}$ is scalar output of ith farm, $X_{i}$ is a vector of output and $\beta$ is a vector of parameters to be estimated, exp is the exponential function, $\mathrm{V}_{\mathrm{i}}$ is a random error having zero mean, which is associated with random factors (e.g. measurement errors in production, weather, industrial action, etc.) not under the control of the farm. $U_{i}$ is factors which are under farm or farmer's control. It is assumed to be independently and symmetrically distributed and half normal (Aigner et al., 1977). The model is such that the possible production, $\mathrm{Y}_{\mathrm{i}}$ is bounded above by the stochastic quantity, $\mathrm{f}\left(\mathrm{x}_{\mathrm{i}} ; \beta\right) \exp \left(\mathrm{V}_{\mathrm{i}}\right)$; hence the term stochastic frontier. 


\section{Macrothink}

Journal of Applied Biotechnology

ISSN 2327-0640

2018, Vol. 6, No. 1

The random errors, $\mathrm{V}_{\mathrm{i}}, \mathrm{i}=1,2 \ldots . . \mathrm{N}$, were assumed to be independently and identically distributed as $\mathrm{N}\left(\mathrm{O}, \sigma_{\mathrm{v}}^{2}\right)$ random variables, independent of the $\mathrm{U}_{\mathrm{i}}$ assumed to be non-negative truncations of the $\mathrm{N}\left(\mathrm{O}, \sigma_{\mathrm{v}}^{2}\right)$ distribution (i.e., half normal distribution) or have exponential distribution. Technical efficiency of an individual firm is defined in terms of the ratio of the observed output to the corresponding frontier output, given the levels of inputs used by that firm (Battese, 1991). Thus, the technical efficiency of firm $i$ in the context of the stochastic frontier production function is the same expression as for the deterministic frontier model, namely:

$$
\begin{aligned}
& \mathrm{TE}_{\mathrm{i}}=\mathrm{Y}_{\mathrm{i}} / \mathrm{Y}^{*}{ }_{\mathrm{i}} \\
& =\mathrm{f}\left(\mathrm{X}_{\mathrm{i}} ; \beta\right) \exp \left(\mathrm{V}_{\mathrm{i}}-\mathrm{U}_{\mathrm{i}}\right) / \mathrm{f}\left(\mathrm{X}_{\mathrm{i}} ; \beta\right) \exp \left(\mathrm{V}_{\mathrm{i}}\right) \\
& \quad=\exp \left(-\mathrm{U}_{\mathrm{i}}\right) \\
& \mathrm{TI}_{\mathrm{i}}=1-\mathrm{TE}_{\mathrm{i}}
\end{aligned}
$$

\section{Methodology}

\subsection{Research Design}

Given that this study had the main objective of analyzing technical efficiency of mushroom farmers, the study was quantitative.Wiersma and Jurs (2005) stated that in quantitative research, no experimental variables are manipulated. Variables are studied as they exist in the situation. Quantitative research describes the phenomena in numbers and measures, instead of words (McMillan \& Schumacher, 2006).

\subsection{Sampling Procedure and Data Collection}

The target population was all the current mushroom farmers from the four Agro-ecological zones of Swaziland. A list of 62 current mushroom farmers was obtained from Malkerns Research Station. All 62 farmers were interviewed for data collection.

Data for this research thesis was collected in January 2016. Before the actual survey, the questionnaire was pre-tested on 12 respondents who grow mushrooms. This study used personal interviews that involved face to face encounter with the respondent. A structured questionnaire was administered to all farmers for interview.

The questionnaire captured a good deal of information on different factors and activities relevant to mushroom production: labour availability, activities and facilities, mushroom inventory, mushroom production and marketing, mushroom management. Data that were collected also included quantities and values of variable inputs, farm size, hired labour, and agrochemicals. Others are quantity of spawn used for planting, type of mushroom substrate used, age, sex, and level of education, farming experience and farmer's income.

\subsection{Data Analysis}

Data were analyzed using both regression and descriptive statistics.

3.3.1 Socio Economic Characteristics of Mushroom Farmers That Influence Technical Efficiency in Swaziland

Means, standard deviations, percentages and frequency counts were used in analyzing socio-economic characteristics.

\subsubsection{Determining Technical Efficiency of Mushroom Growers in Swaziland}




\section{Al Macrothink}

The stochastic frontier production function was used to compute the technical efficiency of the farmers.

The general model for this study was as follows:

$$
\mathrm{Y}=\beta_{0} \mathrm{X}_{1}^{\beta 1} \mathrm{X}_{2}^{\beta 2} \mathrm{X}_{3}{ }^{\beta 3} \mathrm{X}_{4}{ }^{\beta 4} \mathrm{e}^{\mathrm{v}-\mathrm{u}}
$$

Where:

$\mathrm{Y}=$ Mushroom output $\left(\mathrm{kg} / \mathrm{m}^{2}\right)$

$\mathrm{X}_{1}=$ Labour used (man-hours)

$\mathrm{X}_{2}=$ Mushroom house size $\left(\mathrm{m}^{2}\right)$

$\mathrm{X}_{3}=$ Amount of spawn used $(\mathrm{g})$

$\mathrm{X}_{4}=$ Type of mushroom substrate used (1=grass, 2=maize stalks, 3= wheat bran, 4=sugarcane bagasse)

$\beta_{0}$ is a constant and $\beta_{1}, \beta_{2}, \beta_{3}, \beta_{4}$ are elasticities to be estimated. Taking the natural logarithm on both sides, in order to be able to use the least squares procedures for estimation, the linear regression specification becomes:

$$
\operatorname{Iny}_{\mathrm{i}=} \ln \beta_{0}+\beta_{1} \operatorname{Inx}_{\mathrm{i} 1}+\beta_{2} \operatorname{Inx}_{\mathrm{i} 2}+\beta_{3} \operatorname{Inx}_{\mathrm{i} 3}+\beta_{4} \operatorname{Inx}_{\mathrm{i} 4}+\left(\mathrm{v}_{\mathrm{i}}-\mathrm{u}_{\mathrm{i}}\right)
$$

Where:

The subscript $i$ indicates the $i$-th farmer in the sample $(i=1,2,3, \ldots . . n)$

In = Natural logarithm

$\left(\mathrm{v}_{\mathrm{i}}-\mathrm{u}_{\mathrm{i}}\right)=\mathrm{e}_{\mathrm{i}}=$ random error term

$\mathrm{v}_{\mathrm{i}}=$ Random error associated with measurement errors in the yields of mushroom

$\mathrm{u}_{\mathrm{i}}=$ are non-negative random error variables which are assumed to account for technical inefficiency in production and are often assumed to be independently distributed such that the technical inefficiency effects for the $\mathrm{i}$-th farmer growing mushroom is normally distributed with mean $\mu$, and variance $6^{2}$

3.3.3 Identifying Factors That Influence Technical Efficiency in Swaziland

The factors affecting technical efficiency were determined by using a two-limit Tobit model using the STATA 12 computer programme.

$$
\mu_{\mathrm{i}}=\delta_{0}+\delta_{1} \mathrm{z}_{\mathrm{i} 1}+\delta 2 \mathrm{z}_{\mathrm{i} 2}+\delta_{3} \mathrm{z}_{\mathrm{i} 3}+\delta_{4 \mathrm{Z}_{\mathrm{i}}}+\delta_{5} \mathrm{z}_{\mathrm{i} 5}+\delta_{6} \mathrm{z}_{\mathrm{i} 6}+\delta_{7} \mathrm{z}_{\mathrm{i} 7}+\delta_{8} \mathrm{z}_{\mathrm{i} 8}
$$

Where $\mu_{\mathrm{i}}$ is technical inefficiency of the ith farmer,

$\delta$ 's are the parameters of the model to be estimated,

$\mathrm{Z}_{\mathrm{ij}} \mathrm{are}$ the values of explanatory variables for the technical inefficiency effects for the $\mathrm{i}$-th farmer as defined below:

$\mathrm{Z}_{1}=$ Age of the farmer (Years)

$\mathrm{Z}_{2}=$ Gender $($ Male $=0$, Female $=1)$

$\mathrm{Z}_{3}=$ Family size (Number)

$Z_{4}=$ Year of farming experience (Years) 
$\mathrm{Z}_{5}=$ Educational level (Literacy Level)

$\mathrm{Z}_{6}=$ Credit access $(\mathrm{Yes}=1, \mathrm{No}=0)$

$\mathrm{Z}_{7}=$ Technical Assistance $(\mathrm{Yes}=1, \mathrm{No}=0)$

$\mathrm{Z}_{8}=$ Other source of income $(\mathrm{Yes}=1, \mathrm{No}=0)$

\section{Results}

\subsection{Socio Economic Characteristics of Mushroom Farmers}

Table 1 shows the socio-economic characteristics of mushroom respondents and Table 2 shows the descriptive statistics for variables used in the study. A majority of the farmers were between the ages of 41 to 50 years $(51.6 \%)$, the minimum age was between 31 years and the maximum age was above 50 years with a mean of 44.64 and standard deviation of 0.69 .

The results of the study indicated that $62.9 \%$ of the respondents were females, while $37.1 \%$ were males. The findings of the study also indicated that $83.9 \%$ of the farmers were married while $9.7 \%$ and $6.5 \%$ were single and divorced respectively. Besides mushroom production, the farmers were actively engaged in other businesses, $67.7 \%$ of the farmers had two or more enterprises, $22.6 \%$ had one enterprise while $9.7 \%$ of the farmers did not have any other income generating project.

A majority of the respondents, $(64.5 \%)$, had between 6 and 10 members in the household. About $16.1 \%$ had between 0 and 5 members, $12.9 \%$ had between 11 and 15 members while only $6.5 \%$ had their household size range equal to or greater than 16 members. Household members had a mean of 8.38 with standard deviation of 0.49 .The implication of the household size for the farmers is that large household size is maintained to ensure adequate supply of family labour for mushroom activities.

A majority of the farmers (35.48\%) had 3 years farming experience in mushrooms, 33, 87\% had 2 years experience and $19 \%$ had 1 year experience. Results for the analysis on educational level of respondents show that $38.7 \%$ had completed secondary and O' level education compared with $16 \%$ who had completed primary education, while $4,8 \%$ and $1,6 \%$ had completed diploma and degree respectively.

Mushroom production was mainly concentrated in the Middleveld as it had $38.7 \%$ of the farmers. The Highveld had $29 \%$ of mushroom farmers, Lubombo had $17.7 \%$ farmers and the Lowveld had the least percentage of mushroom farmers (14.5\%).

Table 1. Socio-economic characteristics of mushroom respondents

Frequency Percentage

\section{Gender}

Female

Male 
$41-50 \quad 32$

2018, Vol. 6, No. 1

Above 50

17

51.6

Marital status

Single

6

9.7

Married

52

83.9

Divorced

4

6.5

\section{Education}

Primary

Secondary

38.7

O'level

38.7

Diploma

24

4.8

Degree

3

1.6

Agro-ecological Zones

Highveld

Middleveld

Lowveld

9

14.5

Lubombo

Other source of income

Zero

One

Two or more

Household size

0-5

6-10

40

64.5

11-15

8

12.9

16 and above

Type of substrate

Grass

Maize stalks

Wheat bran 
Table 2. Descriptive statistics for variables used in the study

\begin{tabular}{lllclc}
\hline Variable & Unit & $\begin{array}{l}\text { Sample } \\
\text { Mean }\end{array}$ & $\begin{array}{l}\text { Std. } \\
\text { Deviation }\end{array}$ & $\begin{array}{l}\text { Min. } \\
\text { Value }\end{array}$ & $\begin{array}{l}\text { Max. } \\
\text { Value }\end{array}$ \\
\hline Age & Years & 44.64 & .69826 & 31 & Above 50 \\
Household Members & Number & 8.3871 & .4870 & 2.00 & 17.00 \\
Amount of spawn & grams & 2.0000 & .78927 & 1.00 & 3.00 \\
Farm Size & $\mathrm{M}^{2}$ & 25.6290 & 16.34990 & 9.00 & 50.00 \\
Farmers Experience & Years & 2.2742 & .88093 & 1.00 & 5.00 \\
Weekly Labour & Man & 10.5726 & 3.89182 & 2.00 & 18.00 \\
& Hours & & & &
\end{tabular}

Characteristics of

Frequency Percentage

Farmers

\section{Gender}

Male

23

37.1

Female

39

62.9

Level of Education

Primary

16.1

Secondary

24

38.7

O'level

24

38.7

Diploma

3

4.8

Degree

1

1.6

Access to Credit

Yes

No

Technical Assistance

Yes

No

Other Source of Income

Yes

\subsection{Technical Efficiency of Mushroom Farmers}

The maximum likelihood parameter estimates of the stochastic production function are presented in Table 3. The production elasticities for weekly labour hours, type of substrate and amount of spawn had positive signs in the stochastic production frontier. 


\section{Macrothink

The results show that the derived production elasticity of weekly labour was significant at $1 \%$ level. Weekly labour had the highest coefficient with a value of 0.378 and therefore, it existed as the most limiting factor that greatly determines what mushroom output would be like. An increase in labour would increase crop yield and technical efficiency.

This variable implies that a one percent increase in weekly labour measured by man hours will increase mushroom output by 37 percent. The result is consistent with Alemu et al. (2009) who concluded that labour is the most important source of technical efficiency, especially in developing countries where mechanisation is limited. This is because agriculture is labour intensive.

The type of substrate was also significant at 5\%. This means that an increase in a certain usage of substrate will increase mushroom output by $21 \%$.The other variables such as farm size and amount of spawn were not significant. The farm size had a negative sign but was not significant. The implication is that any increase in the farm size would reduce the returns to be realized from the sales of mushrooms, so an extra cost in inputs does not translate into better returns. These findings are similar to those of Frisvold and Ingram (1994) who found that for small fields the production is normally small, but in terms of productivity they perform better than larger plots.

Table 3. Maximum likelihood estimates of stochastic frontier production function to estimate technical efficiency

\begin{tabular}{lcccc}
\hline Variable & Coefficient & Standard error & t-value & $\mathbf{P}>|\mathbf{t}|$ \\
\hline Constant & 0.387 & 0.586 & 0.66 & 0.509 \\
LnMushroom house & -0.127 & 0.092 & -1.38 & 0.168 \\
size & & & & \\
LnWeekly labour & $0.378^{* *}$ & 0.107 & 3.53 & 0.000 \\
LnAmountof spawn & 0.037 & 0.121 & 0.31 & 0.755 \\
LnTypeof substrate & $0.215^{*}$ & 0.974 & 2.22 & 0.027
\end{tabular}

\section{Variance}

Parameters

Sigma Squared

$0.1508 \quad 0.0272$

Sigma u

0.0047

0.5063

Sigma $\mathrm{v}$

0.3884

0.0349

Lambda

0.0123

0.5098

Log-Likelihood

$-29.344$

Notes: $* *=$ significant at $1 \%$ level, $*=$ significant at $5 \%$ level

It is evident from the study that the estimates for lambda and sigma squared in the study area 
are 0.0123 and 0.1508 respectively and lambda is statistically significant at $1 \%$, indicating a good fitness and correctness of the specified distribution assumption. The lambda is the ratio of the variance of $U$ to the variance of $V$, indicating that, the one sided error term $U$ dominates the symmetric error term $\mathrm{V}$ and so variations in the actual output of mushroom is due to differences in farmers' practices rather than random variation.

\subsection{Distribution of Technical Efficiency}

Table 4 shows the distribution of technical efficiency estimates for mushroom farmers in Swaziland. In the study area, the predicted technical efficiency indices varied among mushroom farmers; ranging from 0.48 and 1.00. This means that mushroom farmers are $48 \%$ below the production frontier. The mean technical efficiency was estimated to be 0.95 or $95 \%$. This indicates that each farmer can increase mushroom output by $5 \%$ using the current input quantities. The most technically efficient participant farmers recorded a score of $100 \%$ whilst the least score was $48 \%$. Table 4 shows that 52 of the farmers had technical efficiencies of 0.96-1.00. The distribution is not wide as shown in Table 4 but a large number of mushroom farmers achieve higher levels of technical efficiency.

Table 4. Frequency distribution of technical efficiency estimates

\begin{tabular}{lccc}
\hline Efficiency Class & Frequency & Percentage \\
\hline$\leq 0.60$ & & 3 & 4.8 \\
$0.61-0.80$ & 4 & 6.5 \\
$0.81-0.95$ & 3 & 4.8 \\
$0.96-1.00$ & 52 & 83.9 \\
Total & 62 & 100 \\
Mean Efficiency & 0.95 & & \\
Minimum & 0.48 & & \\
Maximum & 1.00 & & \\
\hline
\end{tabular}

Source: Own calculation from survey data of 2016.

\subsection{Factors Influencing Technical Efficiency}

Table 5 presents the Tobit regression model results. Technical efficiency (TE) is calculated from the following: $\mathrm{TE}_{\mathrm{i}}{ }^{=} \exp \left(-\mathrm{u}_{\mathrm{i}}\right) * 100$ (TE is converted into a percent by multiplying this equation by 100). Technical efficiency is calculated using the conditional expectation of the above equation, conditioned on the composed error $\left(\mathrm{e}_{\mathrm{i}}=\mathrm{v}_{\mathrm{i}}-\mathrm{u}_{\mathrm{i}}\right)$, and evaluated using the stochastic frontier production parameters.

The variables gender, age, level of education, technical assistance, experience and credit had positive signs while other variables household size and other source of income had negative signs. Technical assistance was significant at $1 \%$ level. This means that a frequency increase in the engagement of extension officers or private consultants increased technical efficiency by the value of 0.08 . Household size was significant at $5 \%$ level and access to credit being 
significant at $10 \%$ level. Access to credit was the most important factor affecting technical efficiency with the highest coefficient of 0.9129. This indicates that having access to credit increases the chances of a farmer to improve the technical efficiency index by 0.9129 . Farmers with credit access are able to secure enough farming inputs than those that do not have access to credit. This identifies access to credit to be a source of technical inefficiency in the mushroom production process in Swaziland.

The variable household size was found to have a coefficient of-0.1716 and is statistically significant at 5\% level indicating that mushroom productivity is enhanced as the household size decreases. Households with a large number of members can be expected to have a labour advantage than smaller households who are not able to employ hired labour.

The variable farmer's age was positively related to technical efficiency but was insignificant. The estimated coefficient of 0.0149 indicates that an increase in farmer's age by one year will increase the technical efficiency ratio by 0.0149 . The reason for this finding may be that most of the mushroom farmers were old, since $51.6 \%$ of the sampled farmers were between 41 and 50 years. Moreover, older farmers have enough time on farm activities for management whereas younger farmers are often employed off farm and spend less time on crop management. In their study, Battese and Coelli (1995) found age to be positively associated with technical efficiency.

Table 5. Factors affecting technical efficiency of mushroom production

\begin{tabular}{lclcl}
\hline Variable & Coefficient & $\begin{array}{l}\text { Standard } \\
\text { Error }\end{array}$ & t-value & P -value \\
\hline Constant & $0.813^{* * *}$ & 0.265 & 3.07 & 0.009 \\
Gender & 0.0630 & 0.5305 & 0.12 & 0.906 \\
Age & 0.0149 & 0.4024 & 0.04 & 0.97 \\
Household size & $-0.1716^{* *}$ & 0.0757 & -2.27 & 0.028 \\
Level of Education & 0.2695 & 0.3044 & 0.89 & 0.380 \\
Experience & 0.1629 & 0.3084 & 0.53 & 0.600 \\
Credit Access & $0.9129 *$ & 0.5091 & 1.79 & 0.079 \\
Technical Assistance & $0.077 * *$ & 0.114 & 0.68 & 0.037 \\
Other source of income & -0.6175 & 0.3888 & -1.59 & 0.118 \\
Log likelihood & -124.3362 & & & \\
\hline
\end{tabular}

Notes: $*=$ significant at $10 \%$ level, $* *=$ significant at $5 \%$ level, $* * *=$ significant at $1 \%$ level

Source: Own calculations from the survey data of 2016.

\section{Conclusion and Recommendations}

\subsection{Conclusion}

The findings of the study indicated a mean technical efficiency of $95 \%$ for mushroom farmers 
in Swaziland. This indicates that the farmers can, on average increase their mushroom output by $5 \%$, if they can operate at full technical efficiency. Hence, the null hypothesis stating that mushroom farmers are technically inefficient was rejected and the alternative hypotheses which states that mushroom farmers in Swaziland were technically efficient was accepted.

The variables gender, age, technical assistance, level of education, experience and credit access was positively associated with technical efficiency. The analysis of the determinants of technical efficiency revealed that household size and other source of income had the ability to reduce the chance of farmers to increase technical efficiency.

The study also concludes that there were few male farmers (37.1\%) involved in mushroom growing in Swaziland. This could be as a result of the fact that mushroom growing is seen as a female job. It was noted that farmers were making use of the extension officers as $95.2 \%$ got technical assistance from extension officers.

\subsection{Recommendations}

\subsubsection{Recommendations for Farmers}

The study revealed that from a total of 62 farmers, 95\% was efficient which is a low number of farmers in Swaziland who are capable in farming; therefore farmers are encouraged to participate in mushroom farming.

Farmers can increase their technical efficiency by increasing the amount of spawn and type of substrate used. As it is noted that a majority of the farmers engaged in mushroom production are between the ages of 41-50, older farmers should motivate the youth to be actively involved in mushroom production.

\subsubsection{Recommendations for Policy}

The positive correlation between access to credit and efficiency of the farmers implies that policies that will make agricultural credit from government and Non-Governmental Organisations (NGOs) available to these farmers will go a long way in addressing their resource acquisition problems. This is because the use of agricultural credit to acquire inputs increases technical efficiency and thus shifts the actual production frontier closer to the frontier. Credit is necessary to encourage technical innovations, such as use of yield-enhancing inputs, which cost slightly more, but shifts production and improves the entire input-output relationship.

From the results of the study, output could be increased substantially with current technology and available inputs if technical inefficiency is to be overcome. Policies designed to train mushroom farmers in the four regions of the country through proper machinery could have a great impact in increasing the level of technical efficiency and productivity. More effort should be made on the part of the extension officers in educating the farmers on technologies that will help them boost their efficiency levels.

\subsubsection{Recommendations for Further Study}

Since the mushroom enterprise is primarily targeted to improve rural livelihoods, therefore it is recommended that the role of the mushroom enterprise towards advancing the empowerment of women be studied. The results in chapter three indicated that farmers who participate in the mushroom industry are also engaged in other agricultural enterprises in 
different degrees. Therefore, in attempting to promote diversification towards the mushroom enterprise as an option to reduce farm income variability, it would be useful to conduct further research on possibleenterprise combinations that can generate substantial income at lower risk, taking intoaccount the various challenges faced by the mushroom farmers.

Finally it is recommended that, further studies can be pursued through an extension to cover allocative and economic efficiency, inclusion of additional variables, and increase in sample size with the use of Data Envelopment Analysis (DEA) approach for comparison of results. A study on allocative efficiency would probably give more insight to the efficiency studies.

\section{References}

Abdulai, A., \& Tietje, H. (2007). Estimating technical efficiency under unobserved heterogeneity with stochastic frontier models: Application to northern German dairy farm.

Adeleke, O. A., Fabiyi, Y. L., Ajiboye, A., \& Matanmi, H. M. (2008). Application of Stochastic production frontier in the estimation of technical efficiency of female cassava farmers in Ibadan/Ibarapa agricultural zone of Oyo State, Nigeria.

Aigner, D., Lovell, C. A. K., \& Schmidt, P. (1977). Formulation and Estimation of Stochastic Frontier Production Function Models. Journal of Econometrics, 6, 21-37. https://doi.org/10.1016/0304-4076(77)90052-5

Ajewole, O. C., \& Folayan, J. A. (2008). Stochastic frontier analysis of technical efficiency in dry season leaf vegetable production among smallholders in Ekiti State, Nigeria. Agricultural Journal, 3(4), 252-257.

Battese, G. E. (1991). Frontier production functions and technical efficiency: a surveyof empirical applications in agricultural economics. Journal of Agricultural Economics 7, 185-208. https://doi.org/10.1016/0169-5150(92)90049-5

Battese, G. E., \& Coelli, T. J. (1995). A Model of Technical Inefficiency Effects in a Stochastic Frontier Function for Panel Data. Empirical Economics, 20, 325-332. https://doi.org/10.1007/BF01205442

Chirwa, E. W. (2003). Unpublished Msc Thesis.Sources of technical efficiency among smallholder maize Farmers in Southern Malawi. Department of Economics, Chancellor College, Zomba, Malawi.

Eswaran, A., \& Ramabadran, R. (2000). Studies on some physiological, cultural and post harvest aspects of oyster mushroom, Pleurotuseous. Tropical Agricultural Research, 12, 360-374.

Frisvold, G., \& Ingram, K. (1994). Sources of Agricultural Productivity Growth and Stagnation in Sub- Saharan Africa.Agricultural Economics, 13, 51-61. https://doi.org/10.1016/0169-5150(95)01143-9

Government of Swaziland. (2013). Cost of Hunger in Swaziland Report.

Hassanpour, B. (2012). Factors Affecting Economic Efficiency of Sheep Fattening Industries in Fars Province, Iran. Analysis of Biological Research, 3, 5296-5303. 


\section{Macrothink}

Journal of Applied Biotechnology

ISSN 2327-0640

2018, Vol. 6, No. 1

Kibaara, B. W. (2005). Technical Efficiency in Kenyan's Maize Production: An Application of the Stochastic Frontier Approach.

Oseni, T. O., \& Masarirambi, M. T. (2011). Effects of climate change on maize (Zea mays) production and food security in Swaziland. American-Eurasian Journalof Agricultural Environmental Science, 11(3), 385-391.

Wiersma, W., \& Jurs, S. G. (2005). Research Methods in Education. Pearson Education, Inc. New York, USA.

World Bank Report.High Food Prices. (2008). A Harsh New Reality. Retrieved fromwww.econ.worldbank.org

\section{Copyright Disclaimer}

Copyright reserved by the author(s).

This article is an open-access article distributed under the terms and conditions of the Creative Commons Attribution license (http://creativecommons.org/licenses/by/3.0/). 